ciated with elevated ethylene production is delayed during refrigerated storage. However, the return of fruit to room temperature quickly re-establishes ethylene production and, presumably, the natural progression of senescence underlying the decline in melon shelf-life.

\section{Literature Cited}

Apelbaum, A., A.C. Burgeon, J.D. Anderson, T. Solomos, and M. Lieberman. 1981. Some characteristics of the system converting 1-aminocyclopropane-1-carboxylic acid to ethylene. Plant Physiol. 67:80-84.

Ben-Yehosua, S. 1985. Individual seal-packaging of fruit and vegetables in plastic film-a new postharvest technique. HortScience 20:32-37.

Carter, W.W. 1981. Postharvest treatment for control of stem-scar, rind, and decay fungi on cantaloup. Plant Dis. 65:815-816.

Chan, H. T., Jr., and S.Y.T. Tam. 1982. Partial separation and characterization of papaya endoand exo-polygalacturonase. J. Food Sci. 47:1478-1483.

Chan, H. T., Jr., S. Sanxter, and H.M. Couey. 1985. Electrolyte leakage and ethylene production induced by chilling injury of papayas. HortScience 20:1070-1072.

Chan, H. T., Jr. 1986. Effects of heat treatment on the ethylene forming enzyme system in papayas. J. Food Sci. 51:581-583.

Dunlap, J.R. and C.R. Andersen. 1985. Autoinduction of ethylene biosynthesis in explants from preclimacteric cantaloup fruit. Plant Physiol. $77: 156$.

Hardenburg, R. E., A.E. Watada, and C.Y. Wang, 1986. The commercial storage of fruits, vegetables, and florist and nursery stocks. USDA Agr. Hdbk. 66.

Kader, A.A. 1985. Ethylene-induced senescence and physiological disorders in harvested horticultural crops. HortScience 20:54-57.

Kasmire, R. F., A.V. Sarquis, and D.N. Wright. 1961. Midsummer cantaloupes, p. 18-26. Market quality studies, Univ. of Calif., Agr. Ext. Serv. AXT-50.

Lester, G.E. and B.D. Bruton. 1986. Relationship of netted muskmelon fruit water loss to postharvest storage life. J. Amer. Soc. Hort. Sci. 111:727-731.

Lester, G. E., J.R. Dunlap, and S.E. Lingle. 1988. Effect of postharvest heating on electrolyte leakage and fresh weight loss from stored muskmelon fruit. HortScience 23:407.

Lingle, S. E., G.E. Lester, and J.R. Dunlap. 1987. Effect of postharvest heat treatment and storage on sugar metabolism in polyethylene-wrapped muskmelon fruit. HortScience 22:917-919.

Lipton, W.J. and C.Y. Wang. 1987. Chilling exposures and ethylene treatment change the level of ACC in 'Honey Dew' melons. J. Amer. Soc. Hort. Sci. 112:109-112.

Lipton, W. J., S.J. Peterson, and C.Y. Wang. 1987. Solar radiation influences solar yellowing, chilling injury, and ACC accumulation in 'Honey Dew' melons. J. Amer. Soc. Hort. Sci. 112:503505.

Lizada, M. C. C.-and S.F. Yang. 1979. A simple and sensitive assay for 1-aminocyclopropane-1carboxylic acid. Anal Biochem. 100:140-145.

McGlasson, W.B. 1985. Ethylene and fruit ripening. HortScience 20:51-54.

Neider M., W-K Yip, and S.F. Yang.. 1986. Interferences and specificity of the 1-aminocyclopropane-1-carboxylic acid assay with the hypochlorite reagent. Plant Physiol. 81:156-160.

Ryan, A.L. and W.J. Lipton. 1979. Handling, transportation, and storage of fruits and vege- tables. vol. 1. Vegetables and melons. 2nd ed. AVI, Westport, Corm.

Saltveit, M. E., Jr., and R.M. Cabrera. 1987. Tomato fruit temperature before chilling influences ripening after chilling. HortScience 22:452-454.

Wang, Y.W, and D.O. Adams. 1980. Ethylene production by chilled cucumbers (Cucumis sativus L.). Plant Physiol. 66:841-843.

Wang, Y.W. and D.O. Adams. 1982. Chillinginduced ethylene production in cucumbers (Cucumis sativus L.). Plant Physiol. 69:424427.
Weichmann, J. (cd). 1987. Postharvest physiology of vegetables. Marcel Dekker, New York.

Yang, S.F. and H.K. Pratt. 1978. The physiology of ethylene in wounded plant tissues, p. 596622. In: G. Kahl (ed.). Biochemistry of wounded plant tissues. Walter de Gruyter, Berlin.

Yang, S.F. and N.E. Hoffman. 1984. Ethylene biosynthesis and its regulation in higher plants. Annu. Rev. Plant Physiol. 35:155-189.

Yu, Y-B., D.O. Adams, and S.F. Yang. 1980. Inhibition of ethylene production by 2,4-dinitrophenol and high temperature. Plant Physiol. 66:286-290.

\title{
Conditioning of Florida Grapefruit to Reduce Peel Stress during Low- temperature Storage
}

\author{
W.R. Miller, D. Chun ${ }^{1}$, L.A. Risse, and T.T. Hatton \\ U.S. Department of Agriculture, Agricultural Research Service, 2120 \\ Camden Road, Orlando, FL 32803
}

\section{R.T. Hinsch \\ U.S. Department of Agriculture, Agricultural Research Service, 2021 \\ South Peach Avenue, Fresno, CA 93727}

Additional index words. Citrus paradisi, postharvest, curing, quality, commodity treatment, film wrapping

Abstract. 'Thompson' pink grapefruit (Citrus paradisi Macf.), waxed or film-wrapped, treated with thiabendazole (TBZ) or untreated, were used to determine the effect of high-temperature conditioning at $31 \mathrm{C}$ for 3 days on fruit during subsequent storage for 4 weeks at 1 or $10 \mathrm{C}$. Chilling injury (CI) developed in all conditioned fruit stored at $1 \mathrm{C}$, but was drastically reduced in film-wrapped compared to waxed fruit. Thiabendazole slightly reduced CI, and fruit held at $10 \mathrm{C}$ had fewer CI symptoms than those held at $1 \mathrm{C}$ for 4 weeks. Conditioning Florida grapefruit at $31 \mathrm{C}$ for 3 days did not allow subsequent storage at $1 \mathrm{C}$ without rind discoloration. Chemical name used: 2-(4'-thiazolyl)-benzimidazole (thiabendazol, TBZ).

Grapefruit harvested after 1 Jan. in Florida are generally more susceptible to attack by the Caribbean fruit fly (Anastrepha suspensa Loew.) than early season fruit. All fruit, except those harvested from certified, fly-free zones, must be subjected to an approved quarantine treatment before entry into Japan. The only approved quarantine treatments for grapefruit imported by Japan from Florida are cold treatment and methyl bromide fumigation (U.S. Department of Agriculture, 1976). The cold treatment has proved quite effective for grapefruit, but it must be carefully and precisely conducted by commercial packers or export shippers (Ismail et al., 1986). The approved time/temperature regimes for cold treatment are $0.6 \mathrm{C}$ for 11 days,

Received for publication 20 Mar. 1989. The cost of publishing this paper was defrayed in part by the payment of page charges. Under postal regulations, this paper therefore must be hereby marked advertisement solely to indicate this fact.

'Current address: USDA, ARS, P.O. Box 792, Clemson, SC 29633.
$1.1 \mathrm{C}$ for 12 days, $1.6 \mathrm{C}$ for 14 days, or $2.2 \mathrm{C}$ for 17 days (U.S. Department of Agriculture, 1976). To reduce or eliminate chilling injury (CI), grapefruit must be conditioned for 7 days at $16 \mathrm{C}(90 \% \pm 5 \% \mathrm{RH})$ before the fruit are exposed to the cold treatment (Chalutz et al., 1985; Hatton and Cubbedge, 1981, 1982, 1983). In some commercial lots, however, receivers have observed $\mathrm{CI}$ on grapefruit following cold treatment and subsequent commercial storage and/or transport.

Hopkins and Loucks (1948) reported that "curing" (conditioning) of citrus fruits at $30 \mathrm{C}$ for up to $72 \mathrm{hr}$ provided protection against penicillium rots. Later, Ismail and Brown (1975) and Brown et al. (1978) demonstrated that lignin formation at wounded sites on the peel of oranges held at $30 \mathrm{C}$ for $48 \mathrm{hr}$ provided a barrier that retarded the penetration to injured tissue by the mycelium of Penicillium digitatum.

Thiabendazole was found to reduce $\mathrm{CI}$ as well as decay in grapefruit (Schiffmann-Nadel et al., 1972; Wardowski et al., 1975), and plastic film wrapping reduced $\mathrm{CI}$ in 


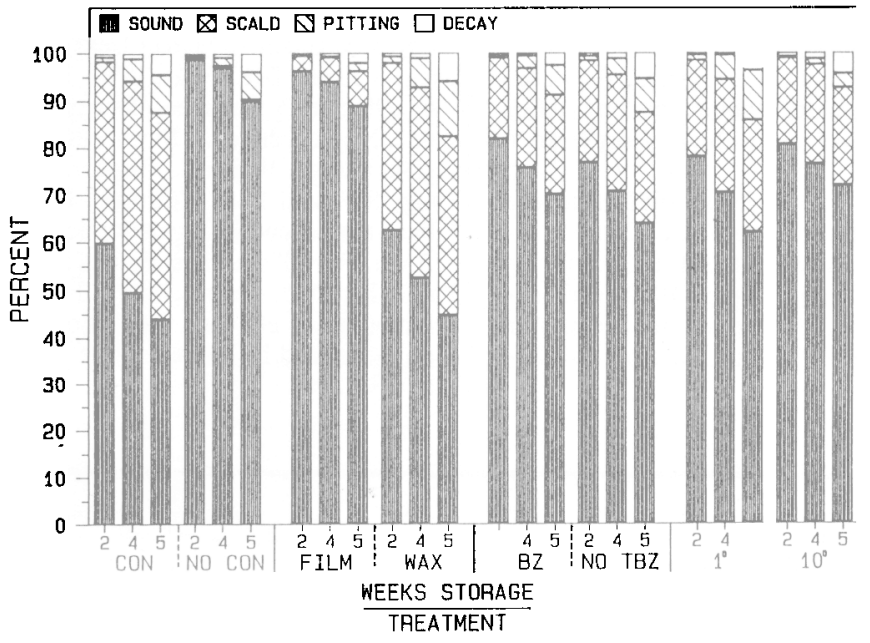

Fig. 1. Means for sound, scalded, pitted, or decayed 'Thompson' pink grapefruit by main treatment effects: conditioning (Con) or nonconditioning; coating (film or wax); thiabendazole (TBZ); and storage temperature (1 or 10C), 2 and 4 weeks of storage at 1 or $10 \mathrm{C}$, and week 5 at $21 \mathrm{C}$. Treatment means represent 480 fruit (i.e., 40 fruit $\times$ three boxes/treatment $\times$ four replications).

Table 1. Index values for firmness and freshness of 'Thompson' pink grapefruit by main factors of conditioning, coating (wax, film-yapped), TBZ, and storage for 2 or 4 weeks at 1 or $10 \mathrm{C}$ plus week 5 at $21 \mathrm{C}$.

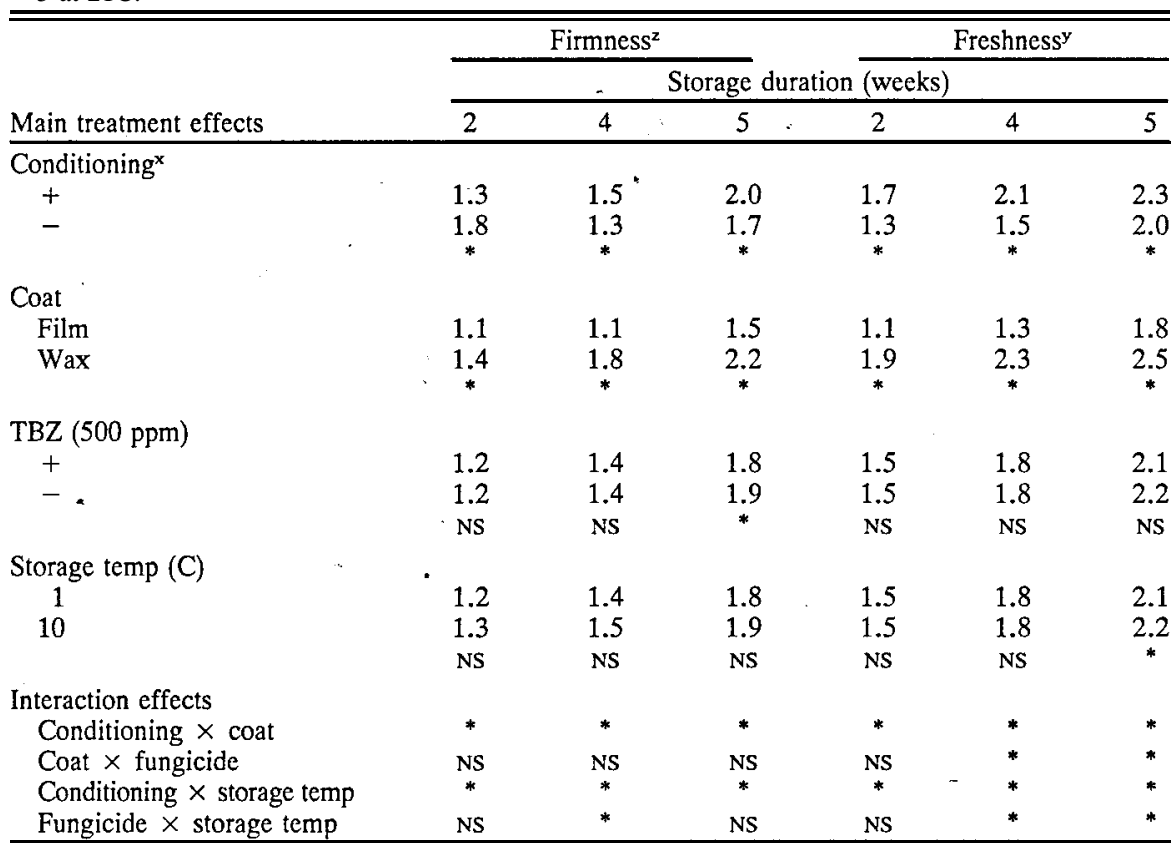

${ }^{2}$ Firmness rating; 1 = firm, 2 = fairly firm, $3=$ soft.

${ }^{y}$ Freshness rating; 1 = fresh, 2 = fairly fresh, $3=$ old

${ }^{x}$ Conditioning regime, $31 \mathrm{C}$ for 3 days.

${ }^{\mathrm{NS}}, *$ Nonsignificant or significant at $P=0.05$, respectively.

grapefruit (Ben-Yehoshua et al., 1981; Purvis, 1985). Film wrapping was not detrimental to the internal quality of grapefruit stored at 5 to $28 \mathrm{C}$ for up to 43 days (Purvis, 1983). Film wrapping of grapefruit reportedly retarded fruit softening, enhanced appearance (Ben-Yehoshua et al., 1981), and promoted wound healing at 20 or 30C (Golomb et al., 1984).

More recently, Ben-Yehoshua et al. (1987a) determined threshold-curing temperatures for film-wrapped lemons and pomelos to be 33 and $36 \mathrm{C}$, respectively, for 3 days and found decay was reduced or eliminated, weight loss and fruit softening were reduced, and there was no alteration in juice flavor during sub- sequent storage. Chun et al. (1988) and Miller et al. (1987) conditioned film-wrapped or waxed Florida grapefruit at $34 \mathrm{C}$ for 3 days. They confirmed earlier observations made by Ben-Yehoshua (1987b) that the effects of conditioning or fruit coating on decay development depended on whether inoculation occurred before or after conditioning. They also found: 1) CI (pitting) was drastically reduced by film wrapping, but not by conditioning; 2) CI (scald) developed on conditioned, waxed fruit, but not on film-wrapped fruit; 3) decay was higher in conditioned fruit held at $1 \mathrm{C}$ than in similar fruit held at $4 \mathrm{C}$; and 4) film-wrapped fruit developed less de- cay than waxed fruit.

The purpose of our study was to combine a high-temperature conditioning treatment with wax or film coating, with or without TBZ applied, to determine a combination treatment that may allow storage of Florida grapefruit at low temperatures to satisfy coldtreatment quarantine procedures without adverse rind damage or decay development.

Size $40(10 \pm 1.3 \mathrm{~cm}$ in diameter $)$ 'Thompson' pink grapefruit were obtained from a packinghouse on the eastern coast of Florida in four separate tests (replications). Harvest dates were 5 and 15 Jan., 3 Feb., and 11 Apr. 1988. Freshly harvested fruit (within $24 \mathrm{hr}$ ) were taken directly from field bins at the packinghouse, transported to the U.S. Horticultural Research Laboratory, Orlando, Fla., and prepared for treatment. Fruit did not require degreening, but-were washed with soap (3\%, Mold Strip 25 Fresh Mark, Ocoee, Fla.). One-half of the fruit in each test was treated with TBZ (500 ppm); the remainder was not treated. Then half of each lot was waxed (Fresh Mark 3202, Orlando, Fla.), and the other half was wrapped individually in plastic heat-shrinkable film (EHC50 DuPont, Wilmington, Del.). Thus, fruit were divided into four treatment combinations and packed 40 fruit per box $\left(0.03 \mathrm{~m}^{3}\right.$, $4 / 5$ bushel), 12 boxes per treatment ( 48 boxes per test). For each treatment, six boxes were not conditioned and six were conditioned at $31 \mathrm{C}$ for $72 \mathrm{hr}$. Nonconditioned fruit were stored at $10 \mathrm{C}$ during the $72-\mathrm{hr}$ conditioning period. After conditioning, half of the fruit in each treatment were stored at $1 \mathrm{C}$ and half at 10C (three, 40 fruit/box subsamples per treatment per storage temperature). The recommended storage temperature for Florida grapefruit harvested after $1 \mathrm{Jan}$. is $10 \mathrm{C}$ and was used as a control. All fruit were evaluated immediately after conditioning, after 2and 4-week storage at 1 or $10 \mathrm{C}$, and after 1 additional week at $21 \mathrm{C}$.

At each evaluation, all fruit were inspected for visible symptoms of aging, pitting, and rind scald. Decayed fruit were removed at each inspection and the primary decay-causing organism was identified and categorized as stem end rot (SER) (Dipodia natalensis P. Evans or Phomopsis citri Fawc.), penicillium rot (PEN ROT) (Penicillium digatatum Sacc. ), or miscellaneous rot (MISC ROT). A collective, subjective score of 1,2 , or 3 , corresponding to fresh, fairly fresh, or not fresh, respectively, was given to fruit on a box-lot basis for freshness of rind and stem scar. Fruit firmness was scored 1 (firm), 2 (fairly firm), or 3 (soft), based on fruit resistance to moderately applied finger pressure.

All data were subjected to statistical analysis using analysis of variance procedure for a $2 \times 2 \times 2 \times 2$ factorial experiment.

Conditioning significantly reduced the percentage of fruit rated sound during the 5week treatment/storage regime (Fig. 1). The development of scald (browning of the rind) was the principal cause for deterioration of conditioned fruit. Scald developed rapidly in conditioned fruit, increasing to $38 \%$ after 2 
weeks of storage, whereas it was $<1 \%$ in nonconditioned fruit after similar storage. Scald accounted for $78 \%$ of unsound fruit, pitting $14 \%$, and decay $8 \%$ at the final inspection. Nearly $90 \%$ of nonconditioned fruit remained sound after 5 weeks of storage.

Film wrapping, as compared to waxing of fruit, significantly reduced rind damage caused by both scald and pitting. Scald did not develop in nonconditioned fruit, regardless of coating, wax, or film wrapping. In conditioned fruit, scald was observed in $70 \%$ of those fruit waxed and stored at 1 or $10 \mathrm{C}$, compared to $14 \%$ of those wrapped in plastic film after 5 weeks of storage.

Film-wrapped fruit that were TBZ-treated and stored at $10 \mathrm{C}$ had the lowest incidence (3\%) of scald of all conditioning treatments after the same storage time. The incidence of pitting was low $(<1 \%$ after 4 weeks of storage) in film-wrapped fruit, regardless of conditioning or storage temperature. The highest incidence of pitting was observed in conditioned fruit that were waxed and stored at $1 \mathrm{C}$, and the lowest was observed in filmwrapped fruit held at $1 \mathrm{C}$. After 5 weeks of storage at $21 \mathrm{C}$, pitting increased to $3 \%$ in film-wrapped fruit previously stored at $1 \mathrm{C}$ for 4 weeks, whereas pitting in similarly held waxed fruit increased to $19 \%$. TBZ-treated waxed fruit that were conditioned had significantly more rind scald than similarly, treated film-wrapped fruit. TBZ was not effective in reducing rind pitting or scald during storage, but significantly reduced decay compared to nontreated fruit.

Fruit stored at $1 \mathrm{C}$ had four times more rind pitting than those stored at 10C. A slight but significant increase in scald occurred at $1 \mathrm{C}$ compared to $10 \mathrm{C}$ after 4 weeks of storage. The precise effect of storage temperature on conditioned fruit that were waxed was difficult to determine because the incidence of scald was exceptionally high in fruit stored at $1 \mathrm{C}$ or $10 \mathrm{C}$ (data not shown).

The principal significant interactions that were consistently expressed during storage duration were: 1) for pitting, the effect of fruit coating, wax, or film depended on storage temperature $(1$ or $10 \mathrm{C}) ; 2$ ) the effect of conditioning on scald development depended on both type of coating and storage temperature.

The main effects and interactions of conditioning, coating, TBZ, and storage temperature on fruit firmness and rind freshness are shown in Table 1.

Although fruit were softened by conditioning after 4 and 5 weeks of storage, the degree of difference was small and of little practical importance. Film-wrapped fruit were significantly firmer than those that were waxed.

Conditioning had a pronounced detrimental effect on rind freshness, and fruit conditioned and waxed were significantly less fresh compared to those conditioned and filmwrapped. Conditioned, waxed fruit deteriorated in freshness more rapidly during storage than fruit of all other treatments.

Based on our investigations, Florida grapefruit are less-tolerant to high-temperature conditioning than citrus produced in Israel (Ben-Yehoshua et al., 1987a). Similarly, in other Florida studies, temperatures of grapefruit during conditioning were 31 or $34 \mathrm{C}$ (Chun et al., 1988; Miller et al., 1987) and scald still developed, especially on waxed fruit. Film wrapping reduced the incidence of rind scald, but did not eliminate. it during 1C storage. However, at $1 \mathrm{C}$, the incidence and severity of scald was less in film-wrapped compared to waxed fruit. Film wrapping drastically reduced CI, as previously reported by Ben-Yehoshua et al. (1981).

The principal purpose for including TBZ in this study was to control decay, provided conditioning caused rind stress that would exacerbate its development. In addition, TBZ is known to reduce symptoms of CI, i.e. pitting or scald. In this study, TBZ did not reduce pitting, but did reduce scald slightly. Using higher concentrations of TBZ might have resulted in greater reductions in CI.

In summary, high-temperature conditioning of Florida grapefruit for 3 days will not allow subsequent storage at $1 \mathrm{C}$ without increasing rind scald and pitting and decreasing fruit freshness and firmness. However, film wrapping drastically reduced, but did not eliminate, scald or pitting of conditioned fruit.

\section{Literature Cited}

Ben-Yehoshua, S., I. Kobiler, and B. Shapiro. 1981. Effects of cooling versus seal-packaging with high-density polyethylene on keeping qualities of various citrus cultivars. J. Amer. Soc. Hort. Sci. 106:536-540.

Ben-Yehoshua, S., E. Barak, and B. Shapiro. 1987a. Postharvest curing at high temperatures reduces decay of individually sealed lemons, pomelos, and other citrus fruits. J. Amer. Soc. Hort. Sci. 112:658-663.

Ben-Yehoshua, S., B. Shapiro, and R. Moran. 1987b. Individual seal packaging enables the use of curing at high temperatures to reduce decay and heal injury of citrus fruits. HortScience 22:777-783.

Brown, G. E., M.A. Ismail, and C.R. Barmore. 1978. Signification of injuries to citrus fruit and susceptibility to green mold. Proc. Fla. State Hort. Soc. 91:124-126.
Chalutz, E., J. Waks, and M. Schiffmann-NadeL 1985. Reducing susceptibility of grapefruit to chilling injury during cold treatment. HortScience 20:226-228.

Chun, D., W.R. Miller, and L.A. Risse. 1988 Grapefruit storage decay and fruit quality after high-temperature prestorage conditioning at high and low humidity. J. Amer. Soc. Hort. Sci. 113:873-876.

Golomb, A., S. Ben-Yehoshua, and Y. Sarig. 1984. High-density polyethylene wrap improves wound healing and lengthens shelf-life of mechanically harvested grapefruit. J. Amer. Soc. Hort. Sci. 109:155-159.

Hatton, T.T. and R.H. Cubbedge. 1981. Effects of ethylene on chilling injury and subsequent decay of conditioned early 'Marsh' grapefruit during low-temperature storage. HortScience 16:783-784.

Hatton, T.T. and R.H. Cubbedge. 1982. Conditioning Florida grapefruit to reduce chilling injury during low-temperature storage. J. Amer. Hort. Sci. 107:57-60.

Hatton, T.T. and R.H. Cubbedge. 1983. Preferred temperature for prestorage conditioning of 'Marsh' grapefruit to prevent chilling injury at low temperatures. HortScience 18:721-722.

Hopkins, E.F. and K.W. Loucks. 1948. A curing procedure for the reduction of mold decay in citrus fruits. Bul. Fla. Agr. Expt. Sta. 450. p. 26.

Ismail, M.A. and G.E. Brown. 1975. Phenolic content during healing of 'Valencia' orange peel under high humidity. J. Amer. Soc. Hort. Sci. 100:249-251

Ismail, M., T.T. Hatton, D.J. Dezman, and W.R. Miller. 1986. In-transit cold treatment of Florida grapefruit shipped to Japan in refrigerated van containers: Problems and recommendations. Proc. Fla. State Hort. Soc. 99:117-121.

Miller, W. R., D. Chun, L.A. Risse, and T.T. Hatton. 1987. Influence of high-temperature conditioning on peel injury and decay of waxed or film-wrapped Florida grapefruit after lowtemperature storage. Proc. Fla. State Hort. Soc. 100:9-12.

Purvis, A.C. 1983. Effects of film thickness and storage temperature on water loss and internal quality of seal-packaged grapefruit. J. Amer. Soc. Hort. Sci. 108:562-566

Purvis, A.C. 1985. Relationship between chilling injury of grapefruit and moisture loss during storage: Amelioration of polyethylene shrink film. J. Amer. Soc. Hort. Sci. 110:385-388.

Schiffmann-Nadel, M., E. Chalutz, J. Waks, and F.S. Lattar. 1972. Reduction of pitting of grapefruit by thiabendazole during long-term cold storage. HortSciencc 7:394-395.

U.S. Department of Agriculture. Animal and plant health protection services. 1976. Plant Protection and Quarantine Treatment Manual. T107 revised Apr. 1985, Washington, D.C.

Wardowski, W. F., L.G. Albrigo, and W. Grierson. 1975. Chilling injury and decay of grapefruit as affected by thiabendazole, benomyl, and $\mathrm{CO}_{2}$. HortScience 10:381-383. 